\title{
A NEW SPECIES OF STANHOPEA (ORCHIDACEAE) FROM PERU
}

\author{
RUDOLF JENNY \\ Moosweg 9, 3112 Allmendingen, Switzerland \\ RJenny@io3s.com
}

\begin{abstract}
A new species of Stanhopea, recently collected in Peru, is described and illustrated. Although allied with the well known Stanhopea haseloviana Rchb.f., the new species Stanhopea manriquei differs by flower size and morphology.
\end{abstract}

ReSUMEN. Se describe y se ilustra una nueva especie de Stanhopea, recién recolectada en Perú. Aunque afín a la bien conocida Stanhopea haseloviana Rchb.f., la nueva especie, Stanhopea manriquei, se diferencia por el tamaño y la morfología de las flores.

Key words / Palabras ClaVE: Orchidaceae, Stanhopea, Stanhopea manriquei, Peru

As a result of the publication of the first part of the monograph about the genus Stanhopea I received quite a few unknown Stanhopeas from different sources for determination. From David Bennett Jr. in Lima I got pickled flowers and dried material of two unknown species, both showed up in the collection of Alfredo Manrique and both have been - following David Bennett - collected somewhere in the Department Puno without further information about exact locality or altitude. Rather fast it was clear that Bennett's number $B-7988$ was indeed a new and undescribed species, for the first view somehow similar to S. haseloviana Rchb.f. from Peru or S. inodora Lodd.ex Lindl. from Central-America but smaller and very different in color and shape of the hypochile. The lip of $S$. manriquei is $25 \%$ shorter, the hypochile is less saccate and adaxially seen ovate and not subrectangular. Color is often not a very important criterion in the taxonomy of Stanhopea, but the morphology of the flower makes clear that the plant is different from $S$. haseloviana in many aspects. For the time being neither the exact locality nor the pollinator are known. William Nauray delivered later on perfect drawings of both plants.

\section{Stanhopea manriquei Jenny \& Nauray, sp. nova}

TYPE: Peru. Dept. Puno: no location, collected by Alfredo Manrique, flowered in culture 24.2.2002, D. Bennett B-7988 (Holotype: MOL; Isotype: Herb. Jenny).
Stanhopeae haselovianae Rchb.f. similis sed floribus multo parvioribus. Hypochilium planum, modo paulo arcuatum, subtus depressum et intus cum carinis signatis. Sepala aurantiaco-lutea cum maculis rubris annularibus, petala atro-aurantiaco-lutea cum maculis rubris annularibus, labellum aureum, hypochilum dimidio basali atro-rubrum usque purpureum.

Plant epiphytic with creeping rhizome and clustered growths. Pseudobulbs ovoid, strongly ribbed when aged and furrowed, $5 \mathrm{~cm}$ long, 3-4 cm wide, always unifoliate. Leaves coarse and leathery, petiolate, lanceolate, plicate and acute, 20-25 cm long, up to $12 \mathrm{~cm}$ wide, petiole round and one-sidely notched, $5 \mathrm{~cm}$ long. Inflorescence directed downwards from the base of the pseudobulb, up to $10 \mathrm{~cm}$ long, with few (3) loosely arranged flowers, covered by large, spread out broadly triangular and acute bracts. Ovary to $6 \mathrm{~cm}$ long, $0.5-0.6 \mathrm{~cm}$ in diameter, very finely black pilose. Flowers $10 \mathrm{~cm}$ large; sepals orange-yellow with clusters and rings of reddish purple dots, darker on dorsal sepal; petals light orange-yellow, the base intense golden yellow-orange with dark purple to red-purple round spots, above with coalesced reddish purple spots; hypochile of lip golden yellow with a very dark red-purple band with rounded apices which at first glance appear to be large spots but in reality are part of a continuous, oblong band, the underside of the mesochile with a broad band of coalesced purplish red dots and spots, the middle portion with 


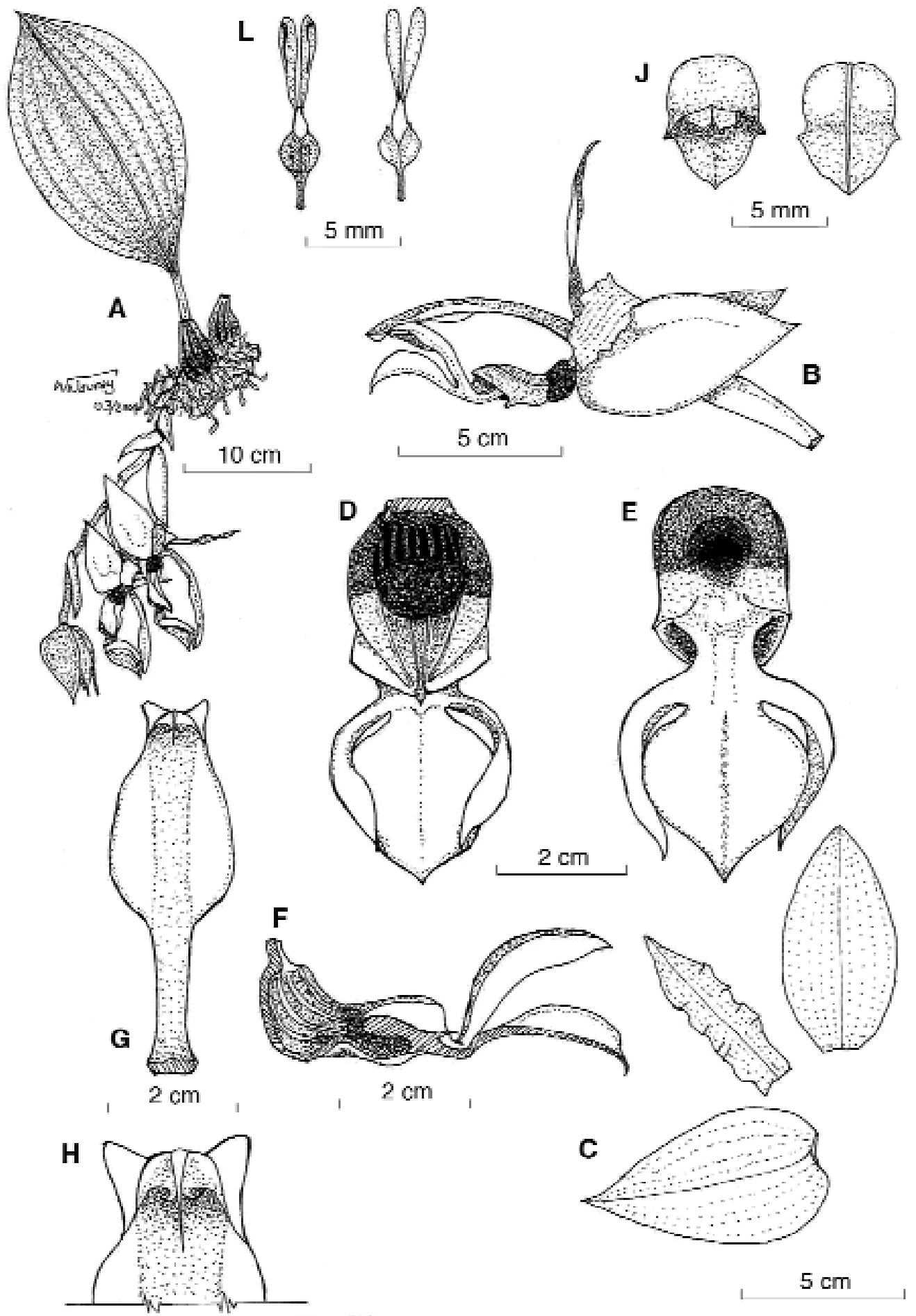

Figure 1. Stanhopea manriquei Jenny \& Nauray. A - Habit. B - Flower. C - Sepals and petal. D - Lip. adaxial view. E - Lip, abaxial view. F - Lip, lateral view. G - Column, adaxial view. H. Apex of column. J. Anther cap. L. Pollinarium. Drawn from the type specimen by W. Nauray. 


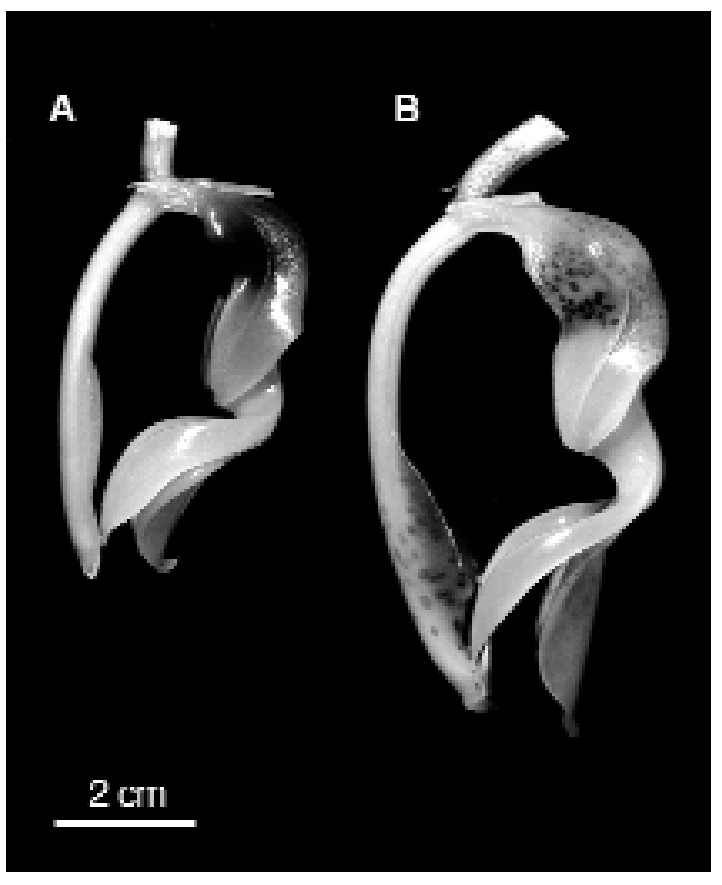

Figure 2. Column and lip of Stanhopea manriquei (A) and S. haseloviana (B), lateral view. Slide R.Jenny.

densely spotted pale rose, underside of the epichile dark cream yellow with purplish dots and short streaks, mesochile dorsally yellow-orange with rose colored spots, inside hypochile densely streaked pale rose coalesced dots and spots, the epichile and horns waxy yellow, the former covered with reddish spots; column jade green with purple spots and dots, wings translucent, the ventral surface spotted and with short dash-like streaks. Dorsal sepal ovate, concave, acute, $7 \mathrm{~cm}$ long, $3.6 \mathrm{~cm}$ wide in the middle. Lateral sepals obtuse, broadly lanceolate, acute, $7.2 \mathrm{~cm}$ long, $4.2 \mathrm{~cm}$ wide at the broadest part in the basic third, folded backwards. Petals oblanceolate, acute, undulate, $6 \mathrm{~cm}$ long, $1.8 \mathrm{~cm}$ broad at the widest part in the middle, folded backwards between dorsal and lateral sepals. Lip over all $6 \mathrm{~cm}$ long, $3 \mathrm{~cm}$ wide across epichile and horns; hypochile only a bit narrower than epichile, flat, dented at ventral side, dorsally with a rather unclear knee; hypochile opening ovate, bridge narrow

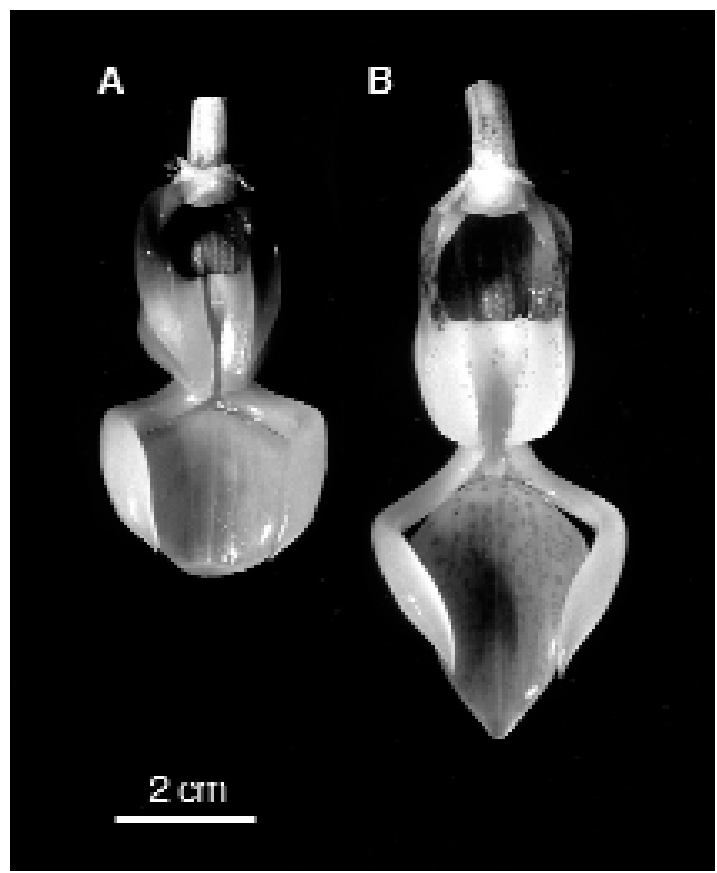

Figure 3. Lip of Stanhopea manriquei (A) and $S$. haseloviana (B), adaxial view. Slide R.Jenny.

triangular, with bulging edges, outer edge marked and bent over the entire lenght of the hypochile, in front ending bluntly triangular at the bridge, with longitudinal carinae within; hypochile transition to mesochile with a sharp edge all round, not set off and not set back, with a small, triangular callus between the basis of the horns at the mesochile; mesochile short, horns narrow at base, towards apex again slightly broadened, flat-ovate in cross-section, acute; epichile ovate with beak-like extended apex. Column slender and bent at base, broadly rounded and winged in the middle, getting narrower again in front, at apex slightly wider and ending both sides of the anther in two blunt, somewhat protruding small horns, $6 \mathrm{~cm}$ long, $1.8 \mathrm{~cm}$ wide at the broadest part. Anther cap ivorycream. Pollinia 2, $0.3 \mathrm{~cm}$ long, narrow, club-shaped on narrow stipes; viscidium ovate to cordate, one-sidedly extended with a central purple marking; entire pollinarium $1.0 \mathrm{~cm}$ long. 